\title{
Analysis of The Effect of Motivation, Job Satisfaction, and Organizational Commitment on Performance
}

\author{
Ifan Widarto ${ }^{1}$, Rina Anindita ${ }^{2}$ \\ Magister Manajemen, Universitas Esa Unggul Jakarta, Indonesia ${ }^{1,2}$
}

\begin{abstract}
Human resources have a major role in every organizational activity. The resources of the organization will not provide optimal results if it is not supported by human resources who have a capable performance. To achieve good performance, performance variable cannot stand alone. This means that there are several supporting variables that can affect performance variable. Work motivation, Job Satisfaction, and Organizational Commitment are three variables that have an influence on improving employee performance. This is evidenced by previous researches that have been conducted. However, most of these researches took locus in private organizations or institutions. In this research, we took the place of research in state institutions. The purpose of this research were: First, to find out how work motivation influenced organizational commitment; Second, to find out how job satisfaction influenced organizational commitment; Third, to find out how work motivation influenced performance; Fourth, to find out how job satisfaction influenced performance: and Fifth, to find out how organizational commitment influenced performance. This research was conducted on respondents where all of them were Civil Servants of the General Secretariat of People's Consultative Assembly (MPR) of the Republic of Indonesia by using questionnaire media. Data analysis in this research used the Structural Equation Modeling (SEM) method. The results of this research suggested that high work motivation had a significant effect on organizational commitment, high job satisfaction would form high organizational commitment, but high work motivation did not affect performance, while high job satisfaction affected partially on performance, and apparently high organizational commitment did not directly affect performance. This research found evidence that organizational commitment was not mediation between work motivation and performance and job satisfaction with performance.
\end{abstract}

Keywords: Motivation, Job Satisfaction, Organizational Commitment, Performance, State Institution.

\section{INTRODUCTION}

Human resources are the most important capital and wealth in every activity of an organization, both government and non-government organizations. Humans as the most important element are absolutely developed and are needed for a company to achieve the goals of the company. Their time, energies, and abilities can truly be used optimally for the interests of the company, as well as for the interests of individuals (Dessler, 2015).

Human resources have a major role in every organizational activity. The resources of the organization will not provide optimal results if it is not supported by human resources who have a capable performance. Employee performance is very important in the company's efforts to achieve its goals. Higher performance implies an increase in efficiency, effectiveness, or higher quality than the completion of a series of tasks that are charged to an employee in an organization or company (Indrasari, 2017). Choong, et al. (2011) through his research showed that work motivation had a significant positive relationship to organizational commitment. When work motivation increases, organizational commitment will also increase. Research conducted by Dragos (2014) proved that there was indeed a clear and strong relationship between motivation and individual performance. The higher the motivation of employees, the more the employee's performance will increase.

Job satisfaction significantly influences the level of employee performance. This is evidenced by Shafique, et al (2018) in his research. Analysis of the relationship between organizational commitment and performance has been done by Rahim, et al. (2016). The results of his research stated that there was a positive and significant relationship between organizational commitment and employee performance. However, in previous studies mentioned, the type of motivation that was raised was intrinsic motivation. The previous studies involved two different institutions, namely state institutions and private institutions. Job satisfaction dimension in previous studies were based on Spector's (1996) theory. In previous studies, the variables studied were only work motivation, job satisfaction, and organizational commitment. Previous studies also stated that work motivation was placed on the dependent variable. Therefore, we will conduct research using types of intrinsic and extrinsic motivation. In addition, the locus taken in this research is a state institution or specifically, General Secretariat of People's Consultative Assembly (MPR) of the Republic of Indonesia. 


\title{
International Advanced Research Journal in Science, Engineering and Technology
}

\author{
Vol. 5, Issue 9, September 2018
}

\section{LITERATURE REVIEW}

\section{Motivation}

Motivational theory became known in the 1950s. In particular, initially there were three motivational theories, among others, the hierarchy of needs theory, two factor theory, and $\mathrm{X}$ and $\mathrm{Y}$ theories. Maslow's hierarchy of needs was motivation theory in psychology which consists of a five-layer model of human needs, often described as a hierarchical level in a pyramid (McLeod, 2017). Maslow divided these human needs into five levels, so this motivation theory was referred to as "the five hierarchy of needs".

Herzberg (2008) divided two factors that influenced a person's work in the organization, namely: satisfaction factor, usually also referred to as motivator factor or satisfier. Included in this factor were drivers for achievement and work spirit, including: achievement, recognition, work itself, responsibility, and advancement. The second factor of this theory was the dissatisfaction factor, commonly referred to as the hygiene factor or maintenance factor, which was a factor that was originated from job dissatisfaction. These factors were: company policy and administration, supervision, payroll/salary, interpersonal relations, working condition, job security, and job status. (Herzberg, 2008).

\section{Job Satisfaction}

Job satisfaction was defined by Wexl and Yukl (1984) as generalizations of attitudes toward one's work. A variety of attitudes of a person towards his work reflected a pleasant and unpleasant experience in the healthy work of employees towards working conditions and situations, including wages, social conditions, physical conditions and expectations of future experiences (Indrasari, 2017) .

The theory of job satisfaction according to Wexl and Yukl (1984) was a discrepancy theory. This theory measured a person's job satisfaction by calculating the difference between something that was supposed to be and the perceived reality. So that if the satisfaction was obtained more than desired, then people would be more satisfied, so that there was a discrepancy, but it was a positive discrepancy. A person's job satisfaction depended on the difference between something that was considered to be obtained by what was achieved.

Burt (2000) suggested that there were three factors that could lead to job satisfaction. The first factor was the factor of inter-employee relations, consisting of the relationship between the manager and employees, physical factors and working conditions, social relations between employees, suggestions from co-workers, and emotions and work situations. The second factor was the individual factor, consisting of the attitude of the person towards his job, the age of the person while working, and the gender. While the last factor were external factors, namely employee's family circumstances, recreation and education.

\section{Organizational Commitment}

Luthans (2011) said that organizational commitment was a strong desire to remain as a member of the organization, a desire to strive according to the desires of the organization, certain beliefs, and acceptance of the values and goals of the organization. In other words, it was an attitude that reflected employee loyalty to the organization and the sustainability process where organizational members expressed their concern for the organization and success and continuous progress.

Steers and Porters (1979) in Indrasari (2017) argued that there were several factors that could affect employee commitment to the organization. These factors could be grouped into four categories, namely personal characteristics, which were related to age and tenure, level of education, marital status, and gender. Second, the characteristics of work, which were related to the role, self-employment, autonomy, working hours, challenges in work, and the level of difficulty in work. The third factor was work experience that could be seen as a major socialization force that had an important influence in the formation of psychological ties with organizations. The last factor was the structural characteristics that included promotion opportunities and career advancement, size of the organization, and the level of control that the organization carried out for employees.

Allen and Meyer (1990), suggested that there were three separate dimensions of organizational commitment, namely affective commitment, emotional feeling for the organization and beliefs in its values. The second dimension was continuance commitment, the perceived economic value of surviving in an organization when compared to leaving the organization. The last dimension of organizational commitment was normative commitment, the obligation to survive in the organization for moral or ethical reasons.

Affective Commitment was where a person's emotional involvement in the organization was a feeling of love for the organization. Then, Continuance Commitment was a person's perception of costs and risks by leaving the organization at this time. That was, there were two aspects to ongoing commitment, namely involving personal sacrifice when leaving the organization, and the absence of alternatives available to that person. Finally, normative Commitment was a 


\title{
International Advanced Research Journal in Science, Engineering and Technology
}

\author{
Vol. 5, Issue 9, September 2018
}

moral dimension based on a sense of obligation and responsibility on the organization that employed a person and the choice to stay because of culture and ethics.

\section{Performance}

Performance was needed as an evaluation material for a leader or manager. Performance was also a record of outcomes resulting from certain employees or activities carried out over a certain period of time. Christine, et al. (2010) stated that performance was the achievement of an outcome characterized by one's or group's task expertise on the basis of a predetermined goal.

Mathis and Jackson (2012) argued that one that was used to measure performance was by looking at the dimensions of employee performance. The first employee performance dimension was Quality, the result of the hard work of employees in accordance with the objectives set by the company beforehand. The next performance dimension was Quantity, which was the result of hard work from employees that could reach the maximum scale determined by the company. Next was dimension of Timeliness. With timeliness which was a level that showed that a job could be completed more quickly than a predetermined time, the employee's performance was good. Dimension of Attendance was another thing that employees must maintain. The presence of employees could be a benchmark whether employees liked their work or not.

\section{HYPOTHESIS DEVELOPMENT}

In this research, the exogenous variables were work motivation and job satisfaction. While the endogenous variables were organizational commitment variable and performance variable. These variables will then be explained by the operational definitions of each. The operationalization of variables in a research is important in order to facilitate and direct the preparation of questionnaires. The performance of these employees greatly affects the targets to be achieved by an institution. A performance can be influenced by several factors. Work motivation can directly affect the level of performance of the employee. Even work motivation can also increase employee work commitment so that it will indirectly impact on performance improvement.

In addition to work motivation, the level of employee job satisfaction is also very influential on performance achievement. With high motivation, it will increase the productivity of an employee and in the end each employee will have job satisfaction where with high job satisfaction, employees will get better benefits. Good motivation will also increase its organizational commitment where with good motivation to do each job and with good working conditions make employees more comfortable to continue to be able to make a high contribution to the institution. So that there will be organizational commitment from each employee. Yuen, et al. (2011) stated that the main objective of his research was to examine the relationship between intrinsic motivation and organizational commitment. Furthermore intrinsic motivation was significantly correlated with the three components of commitment, namely; affective, continuance and normative commitment. From the results of this research, it also showed that motivation had significantly influenced the organizational commitment of the members of the organization.

Work motivation and organizational commitment are factors that exist within a person who moves his behavior to meet certain goals. Research on these two variables was also carried out by Ahluwalia and Preet (2017). The purpose of their research was to determine whether work motivation had a positive influence on organizational commitment. The results of this research were that there were strong and positive influences to increase commitment in the organization. Variable that was thought to influence the value of organizational commitment was work motivation variable. One of the causes of organizational commitment is not yet optimal is due to low work motivation. This can happen because each individual in the organization is not aware of the importance of these things.

From the above argument, the researcher proposes a hypothesis:

H1: High employee motivation can affect organizational commitment.

High job satisfaction is a sign that a well-managed organization is basically the result of effective behavior management. Job satisfaction is the level of a person's feeling of pleasure as a positive assessment of his work and the environment in which he works. Research on job satisfaction and organizational commitment was done by Agarwal and Sajid (2017) who examined whether there was a strong relationship between job satisfaction and organizational commitment (affective commitment, normative commitment, and ongoing commitment). The result of this research was that job satisfaction was significantly related to organizational commitment, especially affective commitment and normative commitment. Whereas job satisfaction had a weak relationship with ongoing commitment. The influence of job satisfaction with organizational commitment was also examined by Aksoy, et al. (2018). The results of the research were the existence of a strong positive linear relationship between job satisfaction and organizational commitment, especially with affective commitment and normative commitment. While job satisfaction with ongoing commitment had a weak positive linear relationship. 


\section{International Advanced Research Journal in Science, Engineering and Technology}

Vol. 5, Issue 9, September 2018

From the above analysis, the researcher proposes a hypothesis:

H2: High job satisfaction can affect organizational commitment.

Inconsistent motivation causes obstacles to achieving individual goals in the organization and will cause organizational instability and have a very dangerous impact on the survival of the organization itself. Research on the positive relationship between motivation and performance was carried out by Guo, et al. (2014). From the analysis of the research, a statement was produced that motivation and performance had a significant and positive relationship. Motivation is not only owned by formal workers. In all fields, motivation is always meaningful for the perpetrators. What's more, motivation is something that is vital in improving performance. Dragos (2014) conducted research on the relationship of motivation with performance. This research aimed to determine how strong the relationship between motivation and individual performance. The results of the research stated that there was a clear and strong relationship between motivation and individual performance.

From the description above, the researcher can propose a hypothesis, namely:

H3: High work motivation can directly affect employee performance.

The research conducted by Sinulingga and Aseanty (2017) raised job satisfaction and performance as one of the objects of research. They made one hypothesis, namely Job satisfaction had a positive effect on job performance. The result of this research was job satisfaction had a positive and significant effect on performance. Research on whether job satisfaction had a positive effect on performance was carried out by Aslam and Yildirim (2017). Research result obtained was job satisfaction had a very large and significant effect on improving the performance of nurses. Research on the relationship of job satisfaction and performance was also carried out by Shafique, et al. (2018). They examined whether job satisfaction had a positive relationship with employee performance. The result of this research was job satisfaction had a significant effect on the level of performance of the employee.

From the results of some previous studies mentioned above, the researcher make a hypothesis, namely:

H4: High job satisfaction can affect performance.

Two researchers, Conway and Briner (2012) have conducted research involving two variables, namely organizational commitment and performance. The result obtained from this research was: it was indeed proven that there was a very significant relationship between organizational commitment and employee performance. Other researcher who raised the relationship between Organizational Commitment and Performance was Hsu (2012). One of the things raised in his research was whether organizational commitment had a direct effect on performance. This research used the SEM method to process data. The result of this research was that there was a significant relationship between organizational commitment and performance.

Tsui, et al. (2013) conducted a research on the relationship of Organizational Commitment and Performance. The results of the research stated that Organizational Commitment can affect both long-term and short-term performance. Analysis of the relationship between organizational commitment and performance was also carried out by Rahim, et al. (2016). The result of this research stated that there was a positive and significant relationship between organizational commitment and employee performance.

From the explanation of the results of the research above, the researcher put forward a hypothesis, as follows: H5: High organizational commitment can affect performance.

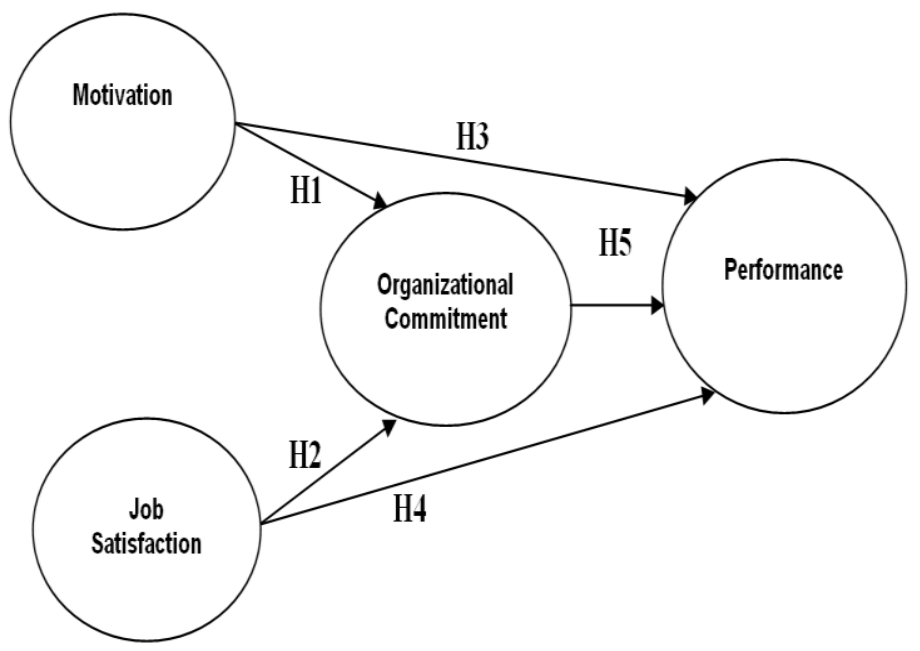

Figure 1. Research Framework 


\title{
International Advanced Research Journal in Science, Engineering and Technology
}

\author{
Vol. 5, Issue 9, September 2018
}

\section{MEASUREMENT}

Indicators of work motivation that were used in this research was Herzberg's Two Factors Theory. This theory consisted of satisfaction, usually also referred to as motivator factor or satisfier. Included in this factor were drivers for achievement and work spirit, including: achievement, recognition, work itself, responsibility, and advancement. The second factor of this theory was the dissatisfaction factor, commonly referred to as the hygiene factor or maintenance factor, which was a factor that originated from job dissatisfaction. These factors were, company policy and administration, supervision, payroll, interpersonal relations, working conditions, job security, and job status. The theoretical guidelines from Wexl and Yukl (1984) were used in the parameters of job satisfaction dimension in this research. This research also placed work motivation as an independent variable. The purpose of this research were: First, to find out how work motivation influenced organizational commitment; Second, to find out how job satisfaction influenced organizational commitment; Third, to find out how work motivation influenced performance; Fourth, to find out how job satisfaction influenced performance: and Fifth, to find out how organizational commitment influenced performance.

The dimensions of organizational commitment revealed by Allen and Meyer (1990), were used in this research. The dimension of affective commitment had pride in the agency as indicator, continuance commitment had the willingness to side or sacrifice for the institution as indicator, and normative commitment had loyalty to the agency as indicator. Motivational theories from Mathis and Jackson (2012) was used in this research. The dimensions that were used in the preparation of the questionnaire were: the quality of work, quantity of work, timeliness, attendance, and ability to cooperate.

\section{RESEARCH METHODOLOGY}

This research was conducted on respondents where all of them were Civil Servants of the General Secretariat of People's Consultative Assembly (MPR) of the Republic of Indonesia. The aspects studied were work motivation, job satisfaction, organizational commitment, and employee performance. The research was conducted in June-July 2018 with the survey method. This research was descriptive analysis. Data collection was carried out by distributing questionnaires to all civil servants of the General Secretariat of People's Consultative Assembly (MPR) of the Republic of Indonesia. Data processing used Structural Equation Modeling (SEM) Method, also known as Structural Analysis Model. In determining the number of samples for SEM according to Hair, et al. (2014), it depended on the number of indicators, then it was multiplied by five. The data collected was then measured by a Likert measurement scale from one to five. The results of the analysis were then interpreted and the final steps were conclusion and suggestion. In this research, the researcher wanted to see the correlation of work motivation with organizational commitment, work motivation with performance, job satisfaction with organizational commitment, job satisfaction with performance, and organizational commitment with performance. Based on the connection structure, the researcher also wanted to know the role of organizational commitment as a mediator in relation to work motivation with performance and job satisfaction with performance. Measurement of work motivation variable was conducted by using indicators based on Herzberg (2008), consisting of 12 indicators; Measurement of job satisfaction was conducted by using indicators adapted from Wexley and Yukl (1984), consisting of seven indicators; Measurement of organizational commitment variable was conducted by using indicators based on Allen and Meyer (2013), consisting of three indicators; and Measurement of performance variable was conducted by using indicators based on Mathis and Jackson (2012) theory, consisting of seven indicators. Subsequently, all indicators were tested through validation and reliability testing.

\section{RESEARCH FINDINGS}

\section{Validity and Reliability Tests}

The measurement of the validity of each research variable was carried out with the Kaiser-Mayer-Olkin Measure of Sampling Adequancy Bartllet's Test Sphericity. Barlett test of sphericity was done to test whether there were correlations between variables. Validity test on Work Motivation variable was done by testing each dimension, namely Motivator Factor and Hygiene Factor. Validity test results on Work Motivation variable obtained KMO values above 0.500 ( 0.658 in the first validity test, 0.688 in the second validity test, and 0.713 in the third validity test) then factor analysis on Work Motivation variable questionnaire can be accepted.

Validity test on Job Satisfaction variable was done by testing each dimension. For the dimension of the work itself, the validity test was done twice. This was because the first validity test found a statement that must be eliminated (KK5). KMO values above 0.500 (0.574 and 0.704) proved that factor analysis on the validity test of this dimension was acceptable. While the Supervision dimension validity test got a KMO and Anti Image value of 0.500 . This means that the existing statements and dimensional factor analysis can be accepted. Validity test carried out on Organizational Commitment variable was done only once. This was because the value of all statements in this variable was above 


\section{International Advanced Research Journal in Science, Engineering and Technology}

Vol. 5, Issue 9, September 2018

0.500. Factor analysis of these variables can be accepted, because the KMO values obtained were also above the limitation value.

In the Performance variable, the validity test process was carried out three times. The amount of KMO value obtained illustrated that factor analysis was acceptable. This was evidenced by the value of the KMO process results in the three stages of the counting process above 0.500. In addition, statements that were considered valid were eight of the ten statements. The reliability test was carried out using the Cronbach's Alpha method. This test was done by calculating the coefficient of Alpha $(\alpha)$.

Table 1. Reliability Test Results

\begin{tabular}{|c|c|c|c|c|}
\hline VARIABLES & DIMENSION & CRONBACH'S ALPHA & REMARKS & PROCESS \\
\hline \multirow{2}{*}{ MOTIVATION } & Motivator Factor & 0.768 & Reliable & \multirow{2}{*}{ By Dimension } \\
\hline & Hygiene Factor & 0.880 & Reliable & \\
\hline \multirow{2}{*}{ JOB SATISFACTION } & The Job Itself & 0.868 & Reliable & \multirow{2}{*}{ By Dimension } \\
\hline & Supervision & 0.811 & Reliable & \\
\hline \multirow{3}{*}{$\begin{array}{l}\text { ORGANIZATIONAL } \\
\text { COMMITMENT }\end{array}$} & Affective Commitment & \multirow{3}{*}{0.876} & \multirow{3}{*}{ Reliable } & \multirow{3}{*}{ By Variable } \\
\hline & Continuance Commitment & & & \\
\hline & Normative Commitment & & & \\
\hline \multirow{5}{*}{ PERFORMANCE } & Work quality & \multirow{5}{*}{0.868} & \multirow{5}{*}{ Reliable } & \multirow{5}{*}{ By Variable } \\
\hline & Work Quantity & & & \\
\hline & Punctuality & & & \\
\hline & Presence & & & \\
\hline & Ability to cooperate & & & \\
\hline
\end{tabular}

The reliability value of a questionnaire was indicated to have an adequate level of reliability if the Cronbach Alpha coefficient was greater or equal to 0.500. The table above shows the Cronbach Alpha coefficient had good reliability, namely above 0.500. Thus, it can be said that variables of work motivation (0.768), job satisfaction (0.880), organizational commitment and performance can be trusted as data collection tools in this research.

\section{Structural Equation Model (SEM)}

From the results of the data obtained the value which showed a good match, because the value was smaller than $<3$ then the results showed good fit. Chi Square value $=1.887$, RMSEA $=0.063$ showed a good match. ECVI model (1.68) compared to ECVI saturated model (1.86) and ECVI independence model (77.54). The ECVI model was slightly closer to the ECVI saturated model and far from ECVI independence model, or in other words, the ECVI model was closer to saturated than independence. The AIC model (308.75) was compared with the AIC saturated model (342.00) and the AIC independence model (14266.75). AIC model was close to AIC saturated model and far from the AIC independence model. Then it showed good compatibility. The CAIC model (511.33) was much smaller than the CAIC saturated model (1063.68) and also smaller than CAIC independence model (14342.50), so it showed a good match. Normed fit index $(\mathrm{NFI})=0.98($ above 0.90$)$ indicated Good Fit. CFI $=0.99$ (above 0.90) indicated a Good Fit model.

Tucker-Lewis Index or Non normed fit index $(\mathrm{NNFI})=0.99$ (above 0.90) indicated Good Fit. Incremental Fit Index $(\mathrm{IFI})=0.99$ (above 0.90) indicated Good Fit. Relative Fit Index (RFI) $=0.98$ (above 0.90) indicated Good Fit. Parsimonius Normed Fit Index $(\mathrm{PNFI})=0.79$ (above 0.6) was used for model comparison, indicating Good Fit. Critical $\mathrm{N}(\mathrm{CN})=129.75<200$, then the model represented the sample size or Marginal Fit. Root mean Square Residual (RMR) was the average residual value that resulted from fitting between the variance-covariance matrix of the model and the variance-covariance matrix of the data sample. Standardized RMR $=0.030(<0.05)$ indicated good fit. Goodness of Fit Index (GFI) = $0.89(<0.90)$ indicated Good Fit. Adjusted Goodness of Fit Index $($ AGFI $)=0.84(>$ 0.90) indicated Good fit. Parsimony Goodness of Fit Index (PGFI) $=0.64$ was used in the model comparison, showing a value above 0.5 , then the match was sufficient. From the results mentioned, it can be concluded that the Goodness of fit model fulfilled the requirements. 


\section{International Advanced Research Journal in Science, Engineering and Technology}

Vol. 5, Issue 9, September 2018

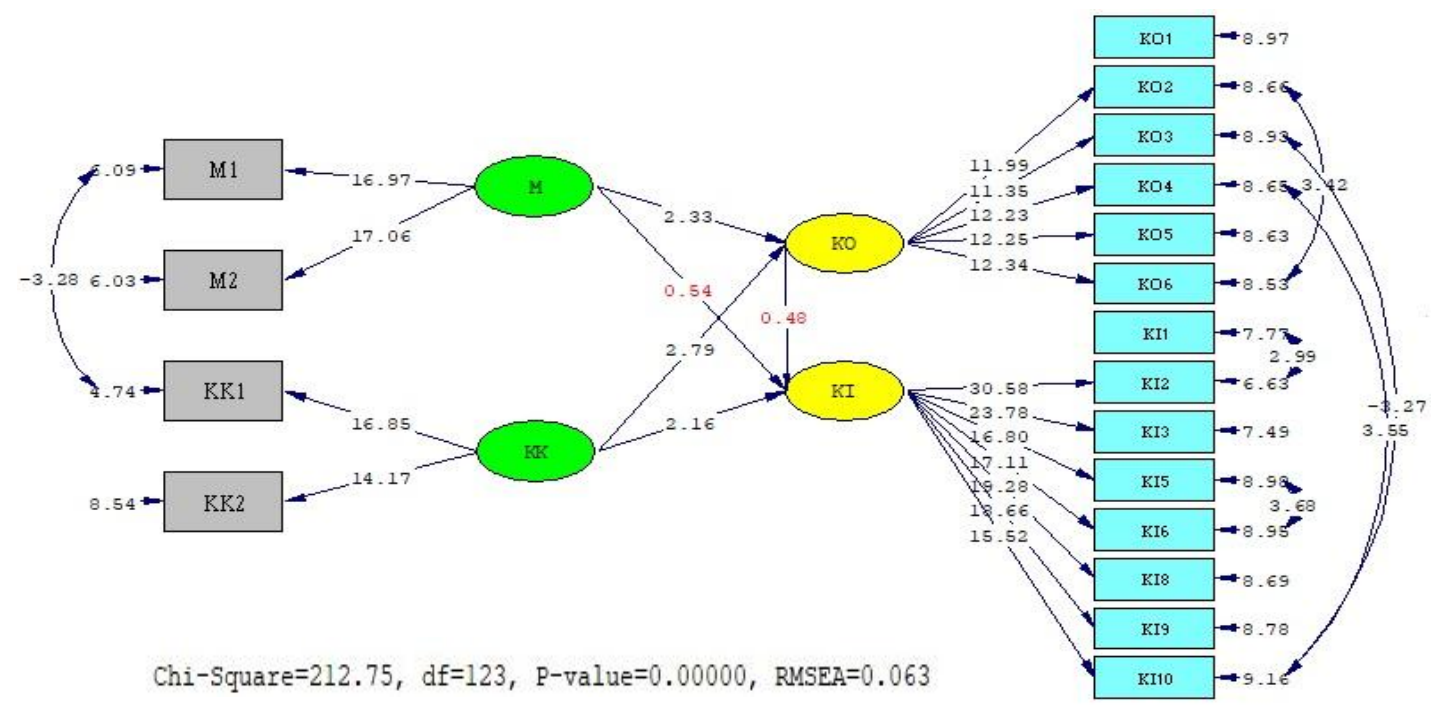

Figure 2. Path Diagram of T-Value

\section{DISCUSSION}

The result of testing the first hypothesis (H1) was that high employee work motivation could significantly improve organizational commitment. The results of this hypothesis reinforced similar research conducted by Batistelli, et al. (2013), Gondokusumo and Sutanto (2015) and Ahluwalia and Preet (2017) which stated that there was a significant relationship between motivation and organizational commitment. The results of this hypothesis test showed that hygiene factor and motivator factor had a significant effect on organizational commitment. The higher the motivation felt by employees, the higher the level of organizational commitment possessed by employees.

The result of testing the second hypothesis (H2) was that high employee job satisfaction could increase organizational commitment and influenced significantly. There was a strong relationship between job satisfaction and organizational commitment (affective commitment, normative commitment, and ongoing commitment) to public sector employees or government agencies. The dimensions that were in job satisfaction had a direct strong influence on increasing organizational commitment. The results of the second hypothesis analysis test reinforced the argument from previous research conducted by Perez, et al. (2017) and Lizote, et al. (2017) which stated that job satisfaction was a very potential factor for increasing organizational commitment. So that job satisfaction had a relationship and a significant influence on organizational commitment. The greater the job satisfaction that was owned by employees, it would have a positive impact on improving organizational commitment. Likewise, the opposite, employee job satisfaction that was not good would significantly reduce organizational commitment.

The result of testing the third hypothesis (H3) was that work motivation was not the main factor in improving performance. There were other variables that had a positive and significant effect on improving performance in addition to work motivation. These variables included compensation, leadership, work discipline, work ability, and working conditions. The results of this analysis were contrary to the results of previous studies conducted by Dragos (2014), Guo, et al. (2014), and Indrasari, et al. (2018). The results of these studies stated that increasing employee motivation would directly affect performance improvement. There was a clear and strong relationship between the motivation employees had on performance. The higher the motivation that employees had, the more the employee's performance would increase.

From the results of the short interview of the researcher on the respondents, a conclusion was obtained that one of the things that caused why motivation could not affect performance was that employees assumed that they did not need to improve the quality of their motivation, because even with the current conditions, all living facilities have been obtained. In addition, the policy of the leader in decision making was often considered not in favor of employees. This automatically added negative factors that prevented employees from improving work motivation. The opportunity for individual employee career development was still far from the ideal word. There were several employees who considered that career development was only obtained by employees who were close to superiors, in other words, there were similar and dislike concepts applied by officials in determining individual employees to occupy a position. The results of this hypothesis were in accordance with previous research conducted by Ismawati, et al. (2017) which stated that motivation did not have a partial effect on employee performance. 


\title{
International Advanced Research Journal in Science, Engineering and Technology
}

\author{
Vol. 5, Issue 9, September 2018
}

The results of testing the fourth hypothesis (H4), namely high job satisfaction could improve performance. The dimensions contained in the variable job satisfaction formed a positive and strong relationship and greatly affected performance improvement significantly. The results of this analysis reinforced the arguments created by previous research. Mouluod, et al. (2016), Alessandri, et al. (2017), Sinulingga and Aseanty (2017), Aslam and Yildirim (2017), and Shafique, et al. (2018) stated that the high job satisfaction achieved by workers would improve even higher performance. Job satisfaction had a very large and significant effect on improving performance. Thus this research was empirically proven that job satisfaction had a positive and significant effect on employee performance.

The result of testing the fifth hypothesis (H5) was that high organizational commitment could not improve performance. The dimensions that existed in organizational commitment variable such as affective commitment, continuance commitment, and normative commitment did not significantly affect employee performance. The results of this analysis was in contrast with the results of previous studies. Conway and Briner (2012), Hsu (2012), Tsui, et al. (2013), Rahim, et al. (2016), and Merry and Syarief (2017) agreed that there was a positive and very significant relationship between organizational commitment and employee performance. The pride of the institution felt by the employees was considered very low. This was caused by several factors, including a sense of fanaticism that was grown and instilled by the agency to employees was not large. Agencies only instilled a boring routine work pattern regardless of how much love employees had for the agency itself. The values applied by the agency may not be the same as the principles that existed in the employee. But the results of this hypothesis were consistent with the research conducted by Chen et al. (2002). They stated that organizational commitment and performance were not too significant or not strongly bound.

\section{CONCLUSION}

There are five conclusions obtained from this research. The first is that high employee work motivation can increase organizational commitment (the first hypothesis can be accepted). This shows that high organizational commitment is influenced by high employee motivation. The indicators contained in the variable of work motivation turned out to have a very large influence on changes in organizational commitment. The next conclusion is that high job satisfaction can increase employee organizational commitment (this hypothesis is acceptable). This means that job satisfaction is a very potential factor for increasing organizational commitment. So that job satisfaction has a relationship and a significant influence on organizational commitment. The third conclusion, the high motivation that employees have does not have a strong influence on improving performance (hypothesis cannot be accepted). The results of this analysis mean that high employee work motivation is not a major factor in improving performance in this institution. The results of this analysis test can represent the conditions of the Civil Servants in the real world. Civil servants in Indonesia, especially in the Secretariat General of People's Consultative Assembly of the Republic of Indonesia, have been spoiled by supporting facilities such as health insurance, retirement insurance and other guarantees that apparently make them comfortable. These guarantees may make most employees stay in the comfort zone. This has an impact on their unwillingness to increase work motivation. Whereas with increasing work motivation will have a direct effect on the quality of individual work and will automatically improve employee performance and can even improve organizational performance.

The next conclusion discusses job satisfaction that can affect performance. The dimensions contained in the variable of job satisfaction can form a positive and strong relationship and greatly affect the performance improvement significantly, so it can be concluded that high job satisfaction has a role in improving employee performance (hypothesis is accepted). A supportive work environment such as the attention given by the leader to themselves and the full authority given to employees to complete their tasks is a form of trust given by the leadership, so that directly or indirectly, employee job satisfaction can be boosted and automatically affect employee performance. The final conclusion is that performance cannot be significantly influenced by organizational commitment or high organizational commitment cannot improve performance (hypothesis cannot be accepted). The dimensions that exist in org anizational commitment variable such as affective commitment, continuance commitment, and normative commitment are not significant in influencing employee performance directly. This is caused by several factors, including a sense of fanaticism that is grown and instilled by the agency to employees is not large. The values applied by the agency may not be the same as the principles that exist in the employee.

\section{LIMITATION OF RESEARCH}

This research has several limitations that can be taken into consideration and correction material for future research. This research uses a questionnaire as a measuring tool because of the need to save time and energy. However, this questionnaire has limitations such as bias in reading statements and filling in answers from respondents. There is a possibility of inconsistency of the respondents in filling out the questionnaire or just filling in based on the expected ideal conditions and not the actual conditions that are happening. This can cause the measurement used does not 


\title{
International Advanced Research Journal in Science, Engineering and Technology
}

\author{
Vol. 5, Issue 9, September 2018
}

describe the variables significantly. In addition, the limited number of samples is 185 people and the number of variables is four variables (motivation, job satisfaction, organizational commitment, and performance) as well as the limited number of dimensions and indicators per variable which causes the research to not explore more about other factors affecting employee performance.

\section{SUGGESTION}

For further studies, this research is still very limited because it is only done in government agencies. Therefore, the researchers suggest that further research be carried out on companies that work together with governments such as State-Owned Enterprises to obtain more objective and representative results with a wider scope. In addition to research development, it is suggested in future studies to add other variables that affect performance. This is because there are many other variables that can optimize these variables.

\section{REFERENCES}

[1]. Agarwal, P., \& Sajid, S.M. (2017). A Study of Job Satisfaction, Organizational Commitment and Turnover Intention among Public and Private Sector Employees. Journal of Management Research. Vol. 17. No. 3. pp. 123-136;

[2]. Ahluwalia, A.K. \& Preet, K. (2017). The Influence of Organizational Commitment on Work Motivation: A Comparative Study of State and Private University Teachers. The IUP Journal of Organizational Behavior. Vol. XVI, No. 2;

[3]. Aksoy, C. Sengün, H.I. Yilmaz, Y. (2018). Examination Of The Relationship Between Job Satisfaction Levels And Organizational Commitments Of Tourism Sector Employees: A Research In The Southeastern Anatolia Region Of Turkey. Electronic Journal of Social Sciences. Vol:17 Issue:65;

[4]. Alessandri, G., \& Borgogni, L. (2016). A Dynamic Model of the Longitudinal Relationship between Job Satisfaction and Supervisor-Rated Job Performance. International Association of Applied Psychology. 66 (2), 207-232;

[5]. Aslan, M., \& Yildirim, A. (2017). Personality and Job Satisfaction among Nurses: The Mediating Effect of Contextual Performance. International Journal of Caring Sciences. Vol 10. Issue 1-544;

[6]. Battistelli, A. Galletta, M. Portoghese, I., \& Vandenberghe, C. (2013). Mindsets of commitment And motivation: interrelationships And contribution to work outcomes. The Journal of Psychology. 147(1), 17-48;

[7]. Chen, et al. (2002). Loyalty to supervisor vs. Organizational commitment: Relationship to employee performance in China. Journal of Occupational and Organizational Psychology. 75, 339-356;

[8]. Choong, Y. O., Wong, K. L., \& Lau, T. C. (2011). Intrinsic Motivation and Organizational Commitment in the Malaysian Private Higher Education Institutions: An Empirical Study. Journal of Arts, Science \& Commerce. Vol.- II, Issue 4;

[9]. Conway, N., \& Briner, R.B. (2012). Investigating The Effect Of Collective Organizational Commitment On Unit-Level Performance And Absence. Journal of Occupational and Organizational Psychology. 85, 472-486;

[10]. Dessler, G. (2015). Manajemen Sumber Daya Manusia. Jakarta: Salemba Empat;

[11]. Dragos, P.F. (2014). Study Regarding The Role Of Motivation In The Sport Performance Activities. Baltic Journal Of Health And Physical Activity. Vol. 6, No. 1, 48-55;

[12]. Gondokusumo, S., \& Sutanto, E.M. (2015). Motivasi Kerja, Kepuasan Kerja, Dan Komitmen Organisasional Karyawan. Jurnal Manajemen dan Kewirausahaan. Vol.17, No. 2, 186-196;

[13]. Guo, y. Liao, j. Liao, s., \& Zhang, y. (2014). The Mediating Role Of Intrinsic Motivation On The Relationship Between Developmental Feedback And Employee Job Performance. Social Behavior \& Personality. 42(5), 731-742;

[14]. Hair, J.E.Jr, et al. (2014). A Primer on Partial Least Squares Structural Equation Modeling (PLS-SEM). California-USA: SAGE Publications, Inc;

[15]. Hsu, J.L. (2012). Effects Of Emotional Labor On Organizational Performance In Service Industry. Pakistan Journal of Statistics. Vol. 28(5), 757-765;

[16]. Indrasari, M. (2017). Kepuasan Kerja dan Kinerja Karyawan: Tinjauan dari Dimensi Iklim Organisasi, Kreativitas Individu, dan Karakteristik Pekerjaan. Sidoarjo: Indomedia Pustaka;

[17]. Indrasari, M.M. Syamsudin, N. Newcombe, P., \& Permana, S. (2018). Influence of Motivation and Quality of Work Life on The Performance of Employees. Jurnal Terapan Manajemen dan Bisnis.Vol 4 Number 1;

[18]. Ismawati, et al. (2017). Pengaruh Motivasi dan Disiplin Kerja terhadap Kinerja Karyawan di Bagian Produksi : Studi Kasus pada PT. Gatra Mapan Ngijo Karangploso. E-Jurnal Riset Manajemen. Prodi Manajemen;

[19]. Lizote, S.A. Verdinelli, M.A., \& do Nascimento, S. (2017). Organizational Commitment And Job Satisfaction: A Study With Municipal Civil Servants. Revista Brasileira de Administração Pública. 51(6):947-967;

[20]. Luthans, J.F., (2011) Perilaku Organisasi (Edisi Sepuluh). (Vivin Andhika Yuwono, Penerjemah).Yogyakarta: Andi;

[21]. Mathis, R.L., \& Jackson, J.H. (2012). Manajemen Sumber Daya Manusia. (Buku 1), (Jimmy Sadeli, Bay, Prawira Hie, Alih Bahasa) Jakarta: Salemba Empat;

[22]. McLeod, Jr.R, \& Schell, G.P. (2017). Sistem Informasi Managemen (Terjemahan). Jakarta: Salemba Empat;

[23]. Merry, L.Z. Syarief, F. (2017). The Effect Of Empowerment, Employee Engagement And Organizational Commitment Towards Performance Of Governmental-Employees Of Financial-Management. International Journal of Human Capital Management. 1(1):152-163;

[24]. Mouluod, K. Boughera, B., \& Samir, B.F. (2016). Job Satisfaction For Physical Education Teachers And Its Relationship To Job Performance And Organizational Commitment. Science, Movement and Health. Vol. XVI, ISSUE 2;

[25]. Pérez, M. Jiménez, M.J.P. Garcés, S.A., \& Sanchez, A.M. (2017). Work-family practices and organizational commitment: the mediator effect of job satisfaction. Universia Business Review. DOI: 10.3232/.V14.N4.03;

[26]. Rahim, N.A.A. Sapian, R.Z.Z. Anuar, A., \& Ismail, A. (2016). Relationship between Performance Based Reward and Organizational Commitment in Banking Industry. Acta Universitatis Danubius. Vol 12, no 3;

[27]. Robbins, S.P. (2015). Perilaku Organisasi. Jakarta: Salemba Empat.

[28]. Shafique, I. Kalyar, M.N., \& Ahmad, B. (2018). The Nexus Of Ethical Leadership, Job Performance, And Turnover Intention: The Mediating Role Of Job Satisfaction. Interdisciplinary Description of Complex Systems. 16(1), 71-87;

[29]. Sinulingga, A.C. \& Aseanty. D. (2017). Peran Kepuasan Kerja Dan Komitmen Afeksi Antara Caring Climate Dengan Kinerja Karyawan. Jurnal Manajemen dan Pemasaran Jasa. Vol. 10 No. 2;

[30]. Spector, P. E., (1996), Industrial and Organizational Psychology: Research and Practice, John Wiley \& Sons, Inc.: United State of America

[31]. Tsui, P.L. Lin, Y.S., \& Yu. T.H. (2013). The Influence Of Psychological Contract And Organizational Commitment On Hospitality Employee Performance. Journal of Social Behavior And Personality. 41(3), 443-452;

[32]. Yuen, Onn Choong., \& Kee, Luen Wong \& Teck, Chai Lau, (2011). Intrinsic motivation and organizational commitment in the Malaysian private higher educat instituitions : An empirical Study. Journal of Arts, Science \& Commerce, E-ISSN 2229-4686, ISSN 2231-4172;

[33]. Yukl, G. (2010), Kepemimpinan dalam organisasi, edisi kelima. Jakarta: PT. Indeks; 